\title{
Biological activity of Herissantia crispa (L.) Brizicky
}

\section{Igara Oliveira Lima, ${ }^{*, 1}$ Vivian Bruna Machado Costa,${ }^{1}$ Wemerson Neves Matias, ${ }^{1}$ Danielly Albuquerque da Costa, ${ }^{2}$ Davi Antas e Silva, ${ }^{1}$ Maria de Fátima Agra, ${ }^{1}$ Maria de Fátima Vanderlei Souza, ${ }^{1}$ Edeltrudes de Oliveira Lima, ${ }^{3}$ Leônia Maria Batista ${ }^{1}$}

${ }^{1}$ Laboratório de Tecnologia Farmacêutica, Departamento de Ciências Farmacêuticas, Universidade Federal da Paraíba, Caixa Postal 5009, 58051-900 João Pessoa-PB, Brazil,

${ }^{2}$ Departamento de Química, Universidade Federal do Piaui, Avenida Campus Ministro Petrônio Portela, S/N, Bloco S2, Ininga, 64049-550 Teresina-PI, Brasil,

${ }^{3}$ Laboratório de Micologia, Departamento de Ciências Farmacêuticas, Universidade Federal da Paraíba, Caixa Postal 5009, 58051-970 João Pessoa-PB, Brazil

\begin{abstract}
RESUMO: “Atividade biológica da Herissantia crispa (L.) Brizicky". O extrato metanólico bruto (EMeOH) das partes aéreas da Herissantia crispa (L.) Brizicky, planta rica em flavonóides e que não possui estudos farmacológicos, foi testada para avaliar sua atividade sob os parâmetros comportamentais e determinar a dose letal $50\left(\mathrm{DL}_{50}\right)$ em camundongos; atividade antimicrobiana e antiulcerogênica. $\mathrm{O} \mathrm{EMeOH}(5000 \mathrm{mg} / \mathrm{kg}$, v.o. ou $2000 \mathrm{mg} / \mathrm{kg}$ i.p.) não alterou os parâmetros comportamentais e não causou mortes nos animais. A amostra vegetal em estudo inibiu o crescimento bacteriano. $\mathrm{O} \mathrm{EMeOH}(750 \mathrm{mg} / \mathrm{kg})$ apresentou atividade anti-diarréica. $\mathrm{O} \mathrm{EMeOH}$ $(250,500$ e $750 \mathrm{mg} / \mathrm{kg}$ ) foi capaz de inibir as lesões gástricas induzidas pelo $0,3 \mathrm{M} \mathrm{HCl} /$ etanol $60 \%$ em camundongos. Desta forma, pode-se concluir que a planta em estudo apresenta atividade antiulcerogênica, entretanto, se faz necessário avaliar tal atividade através de modelos mais específicos e estudar o mecanismo de ação pelo qual a amostra vegetal protege a mucosa gástrica.
\end{abstract}

Unitermos: Herissantia crispa, Malvaecae, avaliação comportamental, atividade antibacteriana, atividade antiulcerogênica.

\begin{abstract}
The crude methanol extract $(\mathrm{EMeOH})$ of the aerial parts of Herissantia crispa (L.) Brizicky, plant riches in flavonoids and without pharmacological studies, was tested to value its activity under the behaviour parameters and to determine the lethal dose $\left(\mathrm{LD}_{50}\right)$ in mice; antimicrobial and antiulcerogenic activities. The $\mathrm{EMeOH}(5,000 \mathrm{mg} / \mathrm{kg}$, v.o. or 2,000 mg/kg i.p.) did not alter the behaviour parameters and there were not mice deaths. The extract inhibited the bacterial growth. The EMeOH $(750 \mathrm{mg} / \mathrm{kg})$ showed anti-diarroeal activity. The EMeOH $(250$, 500 and $750 \mathrm{mg} / \mathrm{kg}$ ) decreased the gastric lesions induced by $0.3 \mathrm{M} \mathrm{HCl} /$ ethanol $60 \%$ in mice. In conclusion, the $\mathrm{EMeOH}$ presents anti-ulcerogenic activity; however it is necessary to value the antiulcerogenic activity in more specific models and to study the action mechanism by which the vegetable sample protects the gastric mucosa.
\end{abstract}

Keywords: Herissantia crispa, Malvaecae, behaviour evaluation, antibacterial activity, antiulcerogenic activity.

\section{INTRODUCTION}

The utilization of medicinal plants to cure human diseases is a fact that is present since antique age (Calixto, 2001). The natural products, like medicinal plants, are font of the synthesis of new bioactive substances (Almeida et al., 2001; Barreto et al., 2004; Rocha et al., 2005; Amaral et al., 2006; Barbosa-Filho et al., 2006a,b, 2007, 2008; Oliveira et al., 2007; Rocha et al., 2007; Saúde-Guimarães \& Faria, 2007; QuintansJúnior et al., 2008; Sousa et al., 2008). The molecular diversity of medicinal plants represents a challenge for the chemists who intend to isolate and determine the structure of active compounds (Hamburger \& Hostettmann, 1991).

The secondary metabolites of medicinal plants are compounds produced by plants with the special functions: defense against microorganisms and predators (herbivores), protection against ultra-violet ray, attractions of pollinator animals (Wink, 1990). These secondary metabolites comprise alkaloids, tannins, cumarins, lignans, ligninins, terpenoids, steroids, fatty acids, flavonoids, etc (Waterman, 1992; Pichersky \& Gang, 2000; Santos, 2004).

The flavonoids are polyphenolics compounds 
with low molecular mass that is distribuitted on the form $\mathrm{C}_{6} \mathrm{C}_{3} \mathrm{C}_{6}$ and they are found in leguminous, fruits, flowers, and leaves (Harbone \& Williams, 2000). The flavonoids show several biological activities, for example, increased skin capillary resistance (Beretz \& Cazenave, 1991); have anti-inflammatory action, modifying the metabolism of platelet arachidonic acid, or blocking both cyclooxygenase and lipooxigenase pathways (Landolfi et al., 1984; Corrêa et al., 2008); antiulcerogenic effect (Beil et al., 1995); antioxidant action (Trueba \& Sanchez, 2001; Trueba, 2003; Zuanazzi \& Montanha, 2004) and antimicrobial activity (Tsuchiya et al., 1996).

The Malvaceae family has 85 genera and 1,500 plants species (Joly, 2002). This family has cosmopolitan distribution and is predominant in the tropics (Joly, 2002; Rocha \& Neves, 2000).

Species of the Malvaceae family like Hibiscus esculentus and Malva neglecta are used in popular medicine for some gastric diseases (i.e. ulcer, stomachache) and they showed antiulcerogenic effect against ulcers induced by ethanol in rats (Gürbuz et al., 2003; Gürbuz et al., 2005).

The species selected for this study was Herissantia crispa (L.) Brizicky (Malvaceae), that does not show popular indication, however, it was choosen according to the chemotaxonomic aspect, because it is rich in flavonoids.

Silva et al. (2005) isolated two flavonoids (kaempferol 3,7-di- $O-\alpha$-L-rhamnoside and kaempferol -3- $\beta-O-\mathrm{D}-(6 "-E-p$-cumaril) glycoside) from $H$. tiubae, another plant of the genus Herissantia. The kaempferol 3,7-di- $O$ - $\alpha$-L- rhamnoside or lespedin caused vasorelaxing effect in rings of mesenteric artery of rats, pre-tensed with phenylephrine (Silva et al., 2005).

Thus, this study aimed investigate the biological activity of $H$. crispa through in vitro experiment, by the antibacterial activity and in vivo experiments, by behaviour evaluation, lethal dose determination $\left(\mathrm{LD}_{50}\right)$, screening anti-ulcerogenic and antidiarrhoeal activities.

\section{MATERIAL AND METHODS}

\section{Botanical material and methanol extract preparation}

Herissantia crispa was collected in the area of Pedra da Boca, municipality of Araruna in the State of Paraíba. It was identified for Dr. Maria de Fátima Agra, botanist from the LTF/UFPB (Voucher 6237 JPB) and deposited in the Herbarium Lauro Pires Xavier of the Departament of Botany - Universidade Federal da Paraíba (UFPB), Brazil.

The aerial parts $(3,000 \mathrm{~g})$ were dried in oven at $50{ }^{\circ} \mathrm{C}$ for 4 days, powdered and macerated with methanol for 3 days. The solution extract was filtered and concentrated under reduced pressure / rotaevaporator at $40{ }^{\circ} \mathrm{C}$, resulting in a concentrated methanol extract weighing $50 \mathrm{~g}$. The yield $(\mathrm{w} / \mathrm{w})$ of the methanol extract $(\mathrm{MeOH})$.

\section{Animals}

Male Swiss mice (27-35 g) were used to do in vivo experiments. They were obtained from Laboratório de Tecnologia Farmacêutica (LTF) / Universidade Federal da Paraíba (UFPB). The animals were fed by a certified to Nuvilab CR-diet with free access to water. They were maintained in clear/dark cycles of $12 \mathrm{~h}$ at 60 $\pm 1 \%$ of humidity and a temperature of $21.5 \pm 2{ }^{\circ} \mathrm{C}$. The experimental protocols were approved by the Institutional Committee for Ethics Animal Research (LTF/UFPB), with register number 0112/06.

\section{Drugs}

Gentamicin $(10 \mu \mathrm{g} / \mathrm{ml})$, obtained from SHERING; Lansoprazole (30 $\mathrm{mg} / \mathrm{kg}$ ) from ACHE; Absolute ethanol from Merck, Germany. The EMeOH of H. crispa was dissolved with saline solution $(0.9 \%)$.

\section{Behavior evaluation and lethal dose determination $\left(\mathbf{L D}_{50}\right)$}

Male and female Swiss mice were separated into groups according to the administration via. Doses of $2,000,1,000,500,250$ and $125 \mathrm{mg} / \mathrm{kg}$ were administrated to the group of intraperitoneal via; while the group of oral via were administrated the doses of 5,000, 2,500, 1,250, and $625 \mathrm{mg} / \mathrm{kg}$. The behavior parameters were observed, like stimulatory, depressor effects and the death, during 4 hours, in the intervals of 30 minutes, 1 hour, 2 hours, 3 hours and 4 hours after the treatment to assess possible clinical or toxicological symptoms (Almeida et al., 1999).

The determination of $\mathrm{LD}_{50}$ was evaluated on mice as described by Souza Brito (1994). The control (saline solution $0.9 \%$ ) and treated groups were observed 30, 60, 120 and 360 min after treatment.

\section{Antibacterial activity}

The antibacterial action of $\mathrm{EMeOH}$ was evaluated using the bacteria: Escherichia coli (ATCC - 11105; ATCC - 10536), Listeria monocytogenes (ATCC - 7664), Yersinea entecrocolytica (ATCC 9610), Shigella flexineri (MM-412), Shigella sonnei (LM-07) and Salmonella spp (LM-08), samples stored of the Laboratório de Micologia / Departamento de Ciências Farmacêuticas (DCF)/ UFPB and Laboratório de Microbiologa / DCF / UFPB. The bacteria were grown in Agar Mueller Hinton (DIFCO Lab. Co). The antimicrobial agent used for control was chloramphenicol at $200 \mu \mathrm{g} / \mathrm{mL}$.

The antibacterial action of $\mathrm{EMeOH}$ was performed by Broth Microdiluition Method as described in National Committee for Clinical Laboratpory Standards with $100 \mathrm{~mL}$ aliquots of diluted $\mathrm{EMeOH}$ and standards antimicrobial agents as controls (gentamicin). Bacterial suspensions were standardized with $0.5 \mathrm{~mL}$ Mc Farland 
Table 1. Antibacterial activity of EMeOH on yeasts of enterobacteria.

\begin{tabular}{|c|c|c|c|c|c|c|c|c|}
\hline \multirow[b]{2}{*}{ Yeasts } & \multicolumn{6}{|c|}{$\mathrm{EMeOH}(\mu \mathrm{g} / \mathrm{mL})$} & \multirow{2}{*}{$\begin{array}{c}\text { Cloramphenicol } \\
200 \mu \mathrm{g} / \mathrm{mL}\end{array}$} & \multirow{2}{*}{$\begin{array}{l}\text { Negative } \\
\text { control }\end{array}$} \\
\hline & 5000 & 2500 & 1250 & 630 & 320 & 150 & & \\
\hline $\begin{array}{l}\text { Escherichia coli } \\
\text { ATCC - } 11105\end{array}$ & - & - & + & + & + & + & - & + \\
\hline $\begin{array}{l}\text { Escherichia coli } \\
\text { ATCC - } 10536\end{array}$ & - & - & + & + & + & + & - & + \\
\hline $\begin{array}{l}\text { Listeria monocytogenes } \\
\text { ATCC - } 7669\end{array}$ & - & - & + & + & + & + & - & + \\
\hline $\begin{array}{l}\text { Shigella flexineri } \\
(\mathrm{MM}-412)\end{array}$ & - & - & + & + & + & + & - & + \\
\hline $\begin{array}{l}\text { Shigella sonnei } \\
\text { (LM-07) }\end{array}$ & - & + & + & + & + & + & - & + \\
\hline $\begin{array}{l}\text { Salmonella spp } \\
\text { LM-08 }\end{array}$ & - & + & + & + & + & + & - & + \\
\hline $\begin{array}{l}\text { Yerisinea entecrocololytica } \\
\text { (ATCC - 9610) }\end{array}$ & - & + & + & + & + & + & - & + \\
\hline
\end{tabular}

+ : growth of bacteria; - : inhibition of bacteria.

Table 2. Antidiarrheal activity of loperamide $(2 \mathrm{mg} / \mathrm{kg})$ and $\mathrm{EMeOH}(250,500$ and $750 \mathrm{mg} / \mathrm{kg})$ in castor oil-induced diarrhea.

\begin{tabular}{l|c|c|c|c}
\hline \multicolumn{1}{c|}{ Treatment } & $\begin{array}{c}\text { Dose } \\
(\mathrm{mg} / \mathrm{kg})\end{array}$ & $\mathrm{N}$ & $\begin{array}{c}\text { Number of wet faeces } \\
\text { (mean } \pm \text { S.D.) }\end{array}$ & $\begin{array}{c}\text { Number of total faeces } \\
\text { (mean } \pm \text { S.D.) }\end{array}$ \\
\hline Saline & - & 6 & $4.7 \pm 0.8$ & $6.3 \pm 1.0$ \\
Loperamide & 2 & 5 & $1.6 \pm 0.5 * *$ & $2.0 \pm 1.2 * *$ \\
EMOH & 250 & 6 & $3.5 \pm 2.3$ & $6.2 \pm 3.1$ \\
& 500 & 5 & $5.0 \pm 1.8$ & $5.8 \pm 0.8$ \\
& 750 & 6 & $1.5 \pm 0.6 * *$ & $2.7 \pm 1.6 * *$ \\
\hline
\end{tabular}

The results are the mean \pm S.D. ANOVA: $F_{(4.23)}=8.5$ for number of wet faeces; $F_{(4,23)}=7.2$ for number of total faeces; $p<0.05$. Followed Dunnett's test: ** $\mathrm{p}<0.01$ compared with the control group (saline).

Table 3. Effects of lansoprazole and EMeOH of Herissantia crispa on $0.3 \mathrm{M} \mathrm{HCl} /$ ethanol $60 \%$ - induced gastric ulcer in mice.

\begin{tabular}{l|c|c|c|c}
\hline \multicolumn{1}{c|}{ Treatment } & $\begin{array}{c}\text { Dose } \\
(\mathrm{mg} / \mathrm{kg})\end{array}$ & $\mathrm{N}$ & $\begin{array}{c}\text { I.L.U. } \\
(\mathrm{mean} \pm \text { S.D. })\end{array}$ & $\begin{array}{c}\text { Inhibition } \\
(\%)\end{array}$ \\
\hline Saline & - & 6 & $267.70 \pm 45.23$ & - \\
Lansoprazole & 30 & 6 & $112.50 \pm 29.17 * *$ & 60 \\
EMOH & 125 & 6 & $213.30 \pm 63.85$ & 20 \\
& 250 & 6 & $134.17 \pm 21.10 * *$ & 50 \\
& 500 & 6 & $129.83 \pm 31.30 * *$ & 52 \\
& 750 & 6 & $103.70 \pm 33.13 * *$ & 61 \\
\hline
\end{tabular}

The results (I.L.U.) are the mean \pm S.D. ANOVA: $\mathrm{F}_{(5.30)}=16.3 ; \mathrm{p}<0.05$. Followed Dunnett's test: ** $\mathrm{p}<0.01$ compared with the control group (saline).

standard (NCCLS, 2000; Cleeland \& Squires, 1991). The minimum bactericidal concentrations were determined by the emergence of a blue color (resazurin) at the wells indicating absence of growth (Mann \& Markham, 1998).

\section{Diarrhoeal induced by castor oil}

The experimental was performed according by Awouters et al. (1978) with some modifications. The animals was fasted by $12 \mathrm{~h}$ and they were distributed in groups who received an oral administration of $\mathrm{EMeOH}$ from $H$. crispa at the respective doses of 250, 500, 750 $\mathrm{mg} / \mathrm{kg}$ and loperamide $(2 \mathrm{mg} / \mathrm{kg})$ or saline $(10 \mathrm{~mL} / \mathrm{kg})$.
After one hour, these animals were treated by castor oil $(0.7 \mathrm{~mL} /$ animal) orally. The severity of diarrheal was observed during 4 hours, and some parameters were analyzed, like total number of faeces and the number of liquid faeces.

\section{Ethanol/HCl-induced gastric lesions}

The experimental was performed according to Mizui \& Doteuchi (1981). After a 24 h fasting, rats (n $=6$ animals for group) received an oral administration of $\mathrm{EMeOH}$ from $H$. crispa at the respective doses of $125,250,500,750 \mathrm{mg} / \mathrm{kg}$ and lansoprazole $(30 \mathrm{mg} / \mathrm{kg})$ 
or saline $(10 \mathrm{~mL} / \mathrm{kg})$. Fifty minutes after treatment, all rats received $0.2 \mathrm{~mL}$ of $0.3 \mathrm{M} \mathrm{HCl} /$ ethanol $60 \%$ to induce gastric ulcer. The animals were killed $1 \mathrm{~h}$ after treatment with the ulcerogenic agent and the stomachs removed and opened along the grater curvature. The ulcerative lesions index (U.L.I.) was calculated according to the methodology described by Szelenyi \& Thiemer (1978).

\section{Statistical analysis}

The results of $\mathrm{LD}_{50}$ and were expressed in mean \pm S.D. followed by Student's t-test using GarphPad Instat, Version 3.00, 1997. The antiulcerogenic activity was expressed in mean $\pm \mathrm{S}$. D. The results were analyzed by One-way analysis of variance (ANOVA) followed by Dunnett's test, with the level of significance $p<0.05$. The software used was GarphPad Instat, Version 3.00, 1997.

\section{RESULTS AND DISCUSSION}

In this work, the biological activities of the EMeOH from $H$. crispa were examined. To investigate the effect of $H$. crispa $\mathrm{EMeOH}$ on the central nervous system (CNS), we used the behavior evaluation model in mice (Almeida et al., 1999) and to determine the lethal dose $\left(\mathrm{LD}_{50}\right)$ on mice, we used the method as described by Souza Brito (1995). These methods were used as an initial part of the pharmacological study of this work. The $\mathrm{EMeOH}$, on the doses and intervals of time valuated, did not alter the behavior parameters and did not cause death in the animals (data not shown). These results suggest that the $\mathrm{EMeOH}$ did not cause changes on the central nervous system (CNS), on these conditions valued.

The acute diarrhea is defined like a disease that there is a lost of $200 \mathrm{~g}$ of faeces on the frequency of three or more times a day, during 14 days; the persistent diarrhea corresponds a period larger than 14 days, and if this disease lasts 30 days or more time, it is defined like chronic diarrhea (Gadewar \& Fosano, 2005).

The diarrhea is a major cause of mortality in children around the world (Pickering, 2004). Salmonella and Shigella species, Escherichia coli (Pickering, 2004), Listeria monocytoglues (Ooi \& Lorber, 2005), Yersinia enterocolytica (Abel-Haq et al., 2000) are the pathogens involved with this disease. The use of antimicrobial agents for treatment of the diarrhea is limited because of the resistance among enteric pathogens. The reason for the resistance is probably associated with the excessive or inappropriate use of antimicrobial agents (Pickering, 2004; Gadewar \& Fosano, 2005). The research of the medicinal plants with antimicrobial activity is increasing, with the objective of finding a drug or phytoconstituent with antimicrobial properties and less collateral effects. The EMeOH of $H$. crispa at 5,000 and $2,500 \mu \mathrm{g} / \mathrm{mL}$ inhibited, respectively, the grown of $100 \%$ and $57 \%$ of yeasts tested in this work (Table 1) and this extract had activity against castor oil - induced diarrhea (Table2).
The peptic ulcer is a disease that shows formation of erosions in the mucosa, reaching the muscular layer of any part of the gastrointestinal tract (Brzozowski, 2003). The ulcer localized in the stomach is called gastric ulcer. The gastric ulcers are produced when defenses (mucous, prostaglandin, blood flow, etc.) are decreased and/or the aggressive factors $(\mathrm{HCl}$, ethanol, Helicobacter pylori, stress etc) are increased (Bandyopadhyay et al., 2001).

The ethanol is an inductive agent of gastric lesions, what mimics the ulcer in the human, because it causes cell damage and disturbance on the blood flow (Brzozowski, 2003); it provokes arteriolar dilatation, vasoconstriction and degranulation of mast cells, resulting in hyperemia (Oates \& Hakkinenn, 1988). Kvietys et al. (1990) observed the involvement of neutrophils on the inflammatory process induced by ethanol, that attack the gastric mucosa and this releases inflammatory mediators that are responsible by recruitment of neutrophils. The oxidative stress is also involved on the pathogenesis caused by ethanol, hence the generation of free radicals causes cell and tissue damages, resulting on the gastric lesions (Repetto \& Llesuy, 2002).

The oral administration of $\mathrm{HCl} /$ ethanol solution in mice causes necrotizing lesions in gastric mucosa; it is caused by decrease of mucous layer and the increase of acid secretion (Mizui \& Doutechi, 1981). This factor occurs because that agent causes oxidative stress and lipid peroxidation and DNA fragmentation, resulting in ulcerative lesions (Gonçales et al., 2001).

On the model of ethanol-induced gastric lesions, it was observed that lansoprazole $(30 \mathrm{mg} / \mathrm{kg})$ and the $\mathrm{EMeOH}(250,500$ and $750 \mathrm{mg} / \mathrm{kg})$ significantly reduced the gastric lesions. This result indicates that the plant in study has antiulcerogenic activity. Studies carried out by Gürbüz et al. (2005) evaluated the antiulcerogenic activity of Malva negletcta (Malvaceae) that showed protective action against gastric lesions induced by ethanol in rats. This result agrees with the protective action observed in the present study with the $\mathrm{EMeOH}$ of H. crispa.

\section{CONCLUSIONS}

The results obtained in this study suggest that the $\mathrm{EMeOH}$ of $H$. crispa did not show activity on the central nervous system; and the $\mathrm{EMeOH}$ inhibited the grown of the bacteria and it had activity against diarrhea induced by castor oil in mice. The EMeOH had gastroprotective activity on the $\mathrm{HCl} /$ ethanol-induced gastric lesions. However, more specific studies must be carried out to elucidate the mechanisms involved in these activities.

\section{REFERENCES}

Abel-Haq NM, Asmar BI, Abuhammour WM, Brown WJ 2000. Yersinia enterocolitica infection in children. Pediatr 
Infect Dis J 19: 954-958.

Almeida RN, Falcão ACGM, Diniz RST, Quintanas-Júnior LJ, Polari RM, Barbosa-Filho JM, Agra MF, Duarte JC, Ferreira CD, Antoniolli AR, Araújo CC 1999. Metodologia para avaliação de plantas com atividade no Sistema Nervoso Central e alguns dados experimentais. Rev Bras Farm 80: 72-76.

Almeida RN, Navarro DS, Barbosa-Filho JM 2001. Plants with central analgesic activity. Phytomedicine 8: 310-322.

Amaral FMM, Ribeiro MNS, Barbosa-Filho JM, Reis AS, Nascimento FRF, Macedo RO 2006. Plants and chemical constituents with giardicidal activity. Rev Bras Farmacogn 16 (Supl.): 696-720.

Awouters F, Niemegeers CJ, Lenaerts FM, Janssen PA 1978. Delay of castor oil diarrhoea in rats: a new way to evaluate inhibitors of prostaglandin biosynthesis. $J$ Pharm Pharmacol 30: 41-45.

Bandyopadhyay D, Biswas K, Bhattacharyya M, Reiter RJ, Banerjee RK 2001. Gastric toxicity and mucosal ulceration induced by oxygen-derived reactive species: protection by melatonin. Curr Mol Med 1: 501-513.

Barbosa-Filho JM, Medeiros KCP, Diniz MFFM, Batista LM, Athayde-Filho PF, Silva MS, Cunha EVL, Almeida JRGS, Quintans-Júnior LJ 2006a. Natural products inhibitors of the enzyme acetylcholinesterase. Rev Bras Farmacogn 16: 258-285.

Barbosa-Filho JM, Martins VKM, Rabelo LA, Moura MD, Silva MS, Cunha EVL, Souza MFV, Almeida RN, Medeiros IA 2006b. Natural products inhibitors of the angiotensin converting enzyme (ACE). A review between 1980-2000. Rev Bras Farmacogn 16: 421446.

Barbosa-Filho JM, Nascimento-Júnior FA, Tomaz ACA, Athayde-Filho PF, Silva MS, Cunha EVL, Souza MFV, Batista LM, Diniz MFFM 2007. Natural products with antileprotic activity. Rev Bras Farmacogn 17: 141148.

Barbosa-Filho JM, Alencar AA, Nunes XP, Tomaz ACA, Sena-Filho JG, Athayde-Filho PF, Silva MS, Souza MFV, da-Cunha EVL 2008. Sources of alpha-, beta, gamma-, delta- and epsilon-carotenes: A twentieth century review. Rev Bras Farmacogn 18: 135-154.

Barreto EJ, Fraga CAM, Araújo JRJX 2004. O uso de produtos naturais vegetais como matérias-primas vegetativas para a síntese e planejamento de fármacos. In: Simões, C.M.O.; Schenkel, E.P.; Gosman, G.; Mello, J.C.P.; Mentz, L.A.; Petrovick, P. R. Farmacognosia - da planta ao medicamento. 5 ed. Porto Alegre/ Florianópolis: Editora da UFRGS/ Editora da UFSC, p. 147-210.

Beil W, Birkholz C, Sewing KF 1995. Effects of flavonoids on parietal cell acid secretion, gastric mucosal prostaglandin production and Helicobacter pylori growth. Arzneimittel-Forsch Drug Res 45: 697-700.

Beretz A, Cazenave JP 1991. Old and new natural products as the source of modern antithrombotic drugs. Planta Med 57: S68-S72.

Bras-Filho R 1994. Química de produtos naturais: importância, interdisciplinaridade, dificuldades e perspectivas. A peregrinação de um pacatubano. Quim Nova 17: 405445.

Brzozowski T 2003. Experimental production of peptic ulcer, gastric damage and cancer models and their use in pathophysiological studies and pharmacological treatment - Polish achievements. J Physiol Pharmacol 54: 99-126.

Calixto JB 2001. Medicamentos Fitoterápicos. In: Yunes, R. A.; Calixto, J.B. Plantas Medicinais - sob a ótica da Química Medicinal Moderna. Chapecó: Argos Editora Universitária, p. 298-315.

Cleeland R, Squires E 1991. Evaluation of new antimicrobials in vitro and in experimental animal infection. In: Lorian, V. Antibiotics in Laboratory Medicine. New York: Williams e Wilkins, p. 739-787.

Corrêa MFP, Melo GO, Costa SS 2008. Substâncias de origem vegetal potencialmente úteis na terapia da Asma. Rev Bras Farmacogn 18 (Supl.): 785-797.

Coutinho HDM, Costa JGM, Siqueira-Júnior JP, Lima EO 2008. In vitro anti-staphylococcal activity of Hyptis martiusii Benth against methicillin-resistant Staphylococcus aureus-MRSA strains. Rev Bras Farmacogn 18 (Supl.): 670-675.

Falcão HS, Mariath IR, Diniz MFFM, Batista LM, BarbosaFilho JM 2008a. Plants of the American continent with antiulcer activity. Phytomedicine 15: 132-146.

Falcão HS, Leite JA, Barbosa-Filho JM, Athayde-Filho PF, Chaves MCO, Moura MD, Ferreira AL, Almeida ABA, Souza-Brito ARM, Diniz MFFM, Batista LM 2008b. Gastric and duodenal antiulcer activity of alkaloids: a review. Molecules 13: 3198-3223.

Gadewar S, Fasano A 2005. Current concepts in the evaluation, diagnosis and management of acute infections diarrhea. Curr Opin Pharmacol 5: 559-565.

Gonçales F, Portela T, Stipp E, Di Stasi L 2001. Antiulcerogenic and analgesic effects of Maytenus aquifolium, Sorocea blomplandii and Zolernia ilicifolia. J Ethnopharmacol 77: 441-447.

Gürbüz I, Üstün O, Yesilada E, Sezik E, Kutsal O 2003. Antiulcerogenic activity of some plants used as folk remedy in Turkey. J Ethnopharmacol 88: 93-97.

Gürbüz I, Özkan AM, Yesilada E, Kutsal O 2005. Antiulcerogenic activity of some plants used in folk medicine of Pinarbasi (Kayseri, Turkey). $J$ Ethnopharmacol 101: 313-318.

Hamburger M, Hostteman K 1991. Bioactivity in plants: the link between phytochemistry and medicine. Phytochemistry 30: 3864-3874.

Harbone JB, Williams CA 2000. Advances in flavonoid research since 1992. Phytochemistry 55: 481-504.

Joly AB 2002. Família Malvaceae. In: Joly, A. B. Botânicaintrodução à taxonomia vegetal, 13. ed. São Paulo: Companhia Editora Nacional, p. 458-461.

Kvietys PR, Twohig B, Danzell J, Specian RD 1990. Ethanolinduced injury to the rat gastric mucosa. Gastroenterol 98: 909-920.

Landolfi R, Mower RL, Steiner M 1984. Modification of platelet function andarachidonic acid metabolism by bioflavonoids. Structure-activity relationships. Biochem Pharmacol 33: 1525-1530.

Mann CM, Markham JL 1998. A new method for determining the minimum inhibitory concentration of essential oils. J Appl Microbiol 84: 538-544.

Mizui T, Doteuchi M 1981. Effect of polyamines on acidified ethanol-induced gastric lesions in rats. Jap $J$ Pharmacol 33: 939-945. 
NCCLS 2000. National Committee for a Clinical Laboratoriay Standards. NCCLS Document M27-A5, Methods for Diluition Antimicrobial Susceptibility Tests for Bacteria that Grow Aerobically; Approved Standard - Fith Edition.

Oates PJ, Hakkienen JP 1988. Studies on the mechanism of ethanol - induced gastric damage in rats. Gastroenterol 94: 10-21.

Oliveira FQ, Gobira B, Guimarães C, Batista J, Barreto M, Souza M 2007. Espécies vegetais indicadas na odontologia. Rev Bras Farmacogn 17: 466-476.

Oliveira IS, Lima JCS, Silva RM, Martins DTO 2008. Triagem da atividade antibacteriana in vitro do látex e extratos de Croton urucurana Baillon. Rev Bras Farmacogn 18: 587-593.

Ooi ST, Lorber B 2005. Gastroenteritis due to Listeria monocytogenes. Clin Infect Dis 40: 1327-1332.

Pichersky E, Gang DR 2000. Genetics and biochemistry of secondary metabolites in plants: an evolutionary perspective. Trends Plant Sci 5: 439-445.

Pickering, LK 2004. Antimicrobial resistance among enteric pathogens. Semin Pediatr Infect Dis 15: 71-77.

Quintans-Júnior LJ, Almeida JRGS, Lima JT, Nunes XP, Siqueira JS, Oliveira LEG, Almeida RN, Athayde-Filho PF, Barbosa-Filho JM 2008. Plants with anticonvulsant properties - a review. Rev Bras Farmacogn 18 (Supl.): 798-819.

Repetto MG, Llesuy SF 2002. Antioxidant properties of natural compounds used in popular medicine for gastric ulcers. Braz J Med Biol Res 35: 523-534.

Rocha JF, Neves LJ 2000. Anatomia foliar de Hibiscus tiliaceus L. e Hibiscus pernambucensis Arruda ( Malvaceae). Rodriguesia 51: 113-132.

Rocha LG, Almeida JRGS, Macedo RO, Barbosa-Filho JM 2005. A review of natural products with antileishmanial activity. Phytomedicine 12: 514-535.

Rocha FD, Pereira RC, Kaplan MAC, Teixeira VL 2007. Produtos naturais de algas marinhas e seu potencial antioxidante. Rev Bras Farmacogn 17: 631-639.

Santos RS 2004. Metabolismo básico e origem dos metabólitos secundários. In: Simões, C.M.; Schenkel, E. P.; Gosmann, G.; Mello, J. C.P.; Mentz, L.A.; Petrovick, P. R. (org) Farmacognosia - da planta ao medicamento. Porto Alegre/Florianópolis: Ed. UFGRS/ Ed. UFSC, p.403-434.

Santos VL, Costa VBM, Agra MF, Silva BA, Batista LM 2007. Pharmacological studies of ethanolic extracts of Maytenus rigida Mart (Celastraceae) in animal models. Rev Bras Farmacogn 17: 336-342.

Saúde-Guimarães DA, Faria AR 2007. Substâncias da natureza com atividade anti-Trypanosoma cruzi. Rev Bras Farmacogn 17: 455-465.

Schmeda-Hirschmann G, Yesilada E 2005. Traditional medicine and gastroprotective crude drugs. J Ethnopharmacol 100: 61-66.

Silva DA, Costa DA, Silva DF, Souza MFV, Agra MF, Medeiros IA, Barbosa-Filho JM, Braz-Filho R 2005. Flavonóides glicosilados de Herissantia tiubae (K. Schum) Brizicky (Malvaceae) e testes farmacológicos preliminares do canferol 3,7-di- $O-\alpha$ L-ramnopiranosídeo. Rev Bras Farmacogn 15: 23-29.

Sousa FCF, Melo CTV, Citó MCO, Félix FHC, Vasconcelos SMM, Fonteles MMF, Barbosa-Filho JM, Viana
GSB 2008. Plantas medicinais e seus constituintes bioativos: Uma revisão da bioatividade e potenciais benefícios nos distúrbios da ansiedade em modelos animais. Rev Bras Farmacogn 18: 642-654.

Souza Brito ARM 1994. Manual de Ensaios Toxicológicos in vivo. Campinas: Editora da Unicamp, p. 22.

Szelenyi I, Thiemer K 1978. Distention ulcer as a model for testing of drugs for ulcerogenic side effects. Arch Toxicol 41: 99-105.

Trueba GP, Sanchez GM 2001. Los flavonóides como antixodantes naturales. Acta Farm Bonaerense 20: 297-306.

Trueba GP 2003. Los flavonóides: antioxidantes o prooxidantes. Rev Cubana Invest Biomed 22: 48-57.

Tsuchiya H, Sato M, Miyazaki T, Fujiwara S, Tanigaki S, Ohyama M, Tanaka T, Iinuma M 1996. Comparative study on the antibacterial activity of phytochemical flavanones against methicillin-resistant Staphylococcus aureus. J Ethnopharmacol 50: 27-34.

Waterman PG 1992. Roles for secondary metabolites in plants. Ciba Found Symp 171: 255-275.

Wink M 1990. Physiology of secondary product formations in plants. In: Charlwood, B.V.; Rhods, M.J.C. (e.d.). Secundary products from plant tissue culture. Oxford:Clarendon.

Zuanazzi JAS, Montanha JA 2004. Flavonóides. In: Simões, C. M. O.; Schenkel, E. P.; Gosman, G.; Mello, J. C. P.; Mentz, L. A.; Petrovick, P. R. Farmacognosia: da planta ao medicamento. 5 ed. Porto Alegre/ Florianópolis: Editora da UFRGS/ Editora da UFSC, p. 577-614. 